\title{
Potential Economic Impacts of COVID-19 on Tourism Industry of Pakistan: A Review
}

\section{COVID-19' un Pakistan Turizm Endüstrisi Üzerindeki Potansiyel Ekonomik Etkileri: Bir İnceleme}

\author{
Nafees MOHAMMAD ${ }^{\mathrm{a} *}$, Lala RUKH ${ }^{\mathrm{b}}$, Farukh KHAN $^{\mathrm{c}}$ \\ ${ }^{\text {a }}$ Prof., University of Peshawar, Department of Environmental Sciences, Peshawar / PAKISTAN \\ ORCID: 0000-0002-8717-8092 \\ ${ }^{\mathrm{b}}$ Student, Qurtaba University, English Literature, Peshawar / PAKISTAN \\ ORCID: 0000-0001-8677-723X \\ ${ }^{\mathrm{c}}$ Student, CECOS University, Department of Civil Engineering, Peshawar / PAKISTAN \\ ORCID: 0000-0002-0189-2376
}

\section{A K A L E B İL G İ S İ}

Makale Geçmişi:

Başvuru tarihi: 19 Mayıs 2020

Kabul tarihi: 6 Ağustos 2020

Anahtar Kelimeler:

COVID-19,

Yurtiçi Turizm,

Teröre Karşı Savaş,

Yabanc1 turistler,

Turizm sektörü,

Ekonomik kayıp

\section{A R T ICLE INFO}

\section{Article History:}

Received May 19, 2020

Accepted August 6, 2020

\section{Keywords:}

COVID-19,

Domestic Tourism,

War Against Terror,

Foreign Tourists,

Tourism Industry,

Economic Loss

\section{Ö Z}

Bu makalede, devam eden COVID-19 salgını nedeniyle beklenen kaybı hesaplamak amacıyla Pakistan'da ic ve dış turizmdeki tarihi eğilimleri gözden geçirme girişiminde bulunulmuştur. Bu amaçla, turizm faaliyetlerinden sağlanan ekonomik büyüme ve COVID-19 vakaları analiz edilmiștir. Bu inceleme, Pakistan'daki turizm faaliyetlerinin yüksek dalgalanmalarla büyüdügünü ortaya koymaktadır. Terörizme karşı bir savaşın yayılmasının ardından Pakistan, 2009 yılında iç turizmi yeniden başlattı. 2010 yılındaki sel, yol ağını tahrip etti ve turizm yeniden azaldı. 2011 yılında turizm departmanı turistik faaliyetleri yeniden çerçevelendirdi. Tahminlere göre, 2012-19 döneminde Pakistan otoyollara, otellere, parklara ve arkeolojik alanlara 90 milyardan fazla rupi yatırdı ve turizmde biraz iyileşme için 2020 yaz sezonunu dört gözle bekliyordu ancak COVID-19 dünya ufkunda belirdi ve turizm dahil her türlü ekonomik faaliyet sıfıra getirildi. 1994-2019 döneminde turizm, Pakistan'ın gayri safi yurtiçi hasılasına (GSYIH) \% 5,7 ila 7,1 oranında katkıda bulunmuștur. Kayıp 20,18 milyar ABD dolarına eșittir. Pakistan birkaç yıl daha acı çekecek. COVID-19 așısı piyasaya çıksa bile, kayıp telafi edilemez olacaktır. Koronavirüs varlığında hayatta kalmayı öğrenmeli ve turizm dahil her işletme için standart operasyon prosedürü (SOP) hazırlamalıyız.

\begin{abstract}
A B S T R A C T
In this article an attempt has been made to review the historic trends in foreign and domestic tourism in Pakistan with the aim to calculate expected loss due to ongoing COVID-19 pandemic. For this purpose gross domestic product (GDP) growth in relation to tourism activities and COVID-19 cases were analyzed. This review revealed that tourist activities in Pakistan are growing with high level of fluctuations. After a spill of war on terrorism, Pakistan re-initiated domestic tourism in 2009. The 2010 flood destroyed the road network and tourism was waned again. In 2011 tourism department re-framed tourist activities again. As per estimate, during 2012-19, Pakistan invested more than 90 billion of rupees on motorways, hotels, parks and archeological sites and was looking forward toward 2020 summer season for some betterment in tourism, but COVID-19 appeared on the world horizon and all sorts of economic activities, including tourism were brought to zero. During 1994-2019 tourism contributed 5.7 to $7.1 \%$ to the gross domestic products (GDP) of Pakistan. The loss is equivalent to US\$20.18 billion. Pakistan will suffer for another few years. Even if the vaccine for covid19 arrives in the market, the loss will be irreparable. We have to learn survival in the presence of coronavirus, and prepare standard operating procedure (SOPs) for each business including tourism.
\end{abstract}

\footnotetext{
* Sorumlu yazar/Corresponding author.

e-posta:nafees@uop.edu.pk
} 


\section{Introduction}

Tourism is a growing economic activity throughout the world. Each country has some uniqueness that attracts tourists. In most cases it the natural set up that attract tourist. According to the estimate of world tourism organization, tourism is growing on the average rate of 4.1 percent and will be a big industry by 2020 (Dwyer, 2005). Study conducted in 2007 revealed that the total global contribution to GDP was $10 \%$ with involvement of 230 million people. In USA the growth rate was recorded as 5\% (Delener, 2010). It is very productive economic activity, but very sensitive also. Various factors can affect tourism and can bring it down to zero. These factors may be natural or man-mad. In natural factors include natural calamities, flood, earth quack, epidemic in man mad factor include war, political relation, internal crises etc. (Chen et al., 2009, Papatheodorou. et al., 2010 and Cohen, 2012).

Pakistan got a unique geographic location with natural diversity, ranging from sea shore to high Himalayan Mountain ranges. People around the year were visiting Pakistan not only to enjoy natural beauty but also archeological and religious monuments. To promote tourism in Pakistan, efforts were initiated in 1972 by creating a separate ministry. Latter on a separate department was established in 1976. Since 1999 Pakistan was with an attempt to introduce the concept of ecotourism. In this regard World Wide Fund for Pakistan took various steps in the northern areas (Israr, et al., 2009). Over the history a lot of ups and downs were observed and Pakistan couldn't shape the tourism in to a real business (Fig. 1). The 2005 earthquake destroyed the infrastructure and put the area in trouble for almost five years. During this period of time tourism was almost zero due to rehabilitation (Haseeb, et al., 2011). Similarly, the 2010 flood damaged the entire rode network at mountainous areas and various areas were not accessible (Asgary, Anjum, \& Azimi, 2012). Besides natural disaster, manmade and political situation also damages tourism activities to

Fig. 1: Percent growth rate during 1995-2018

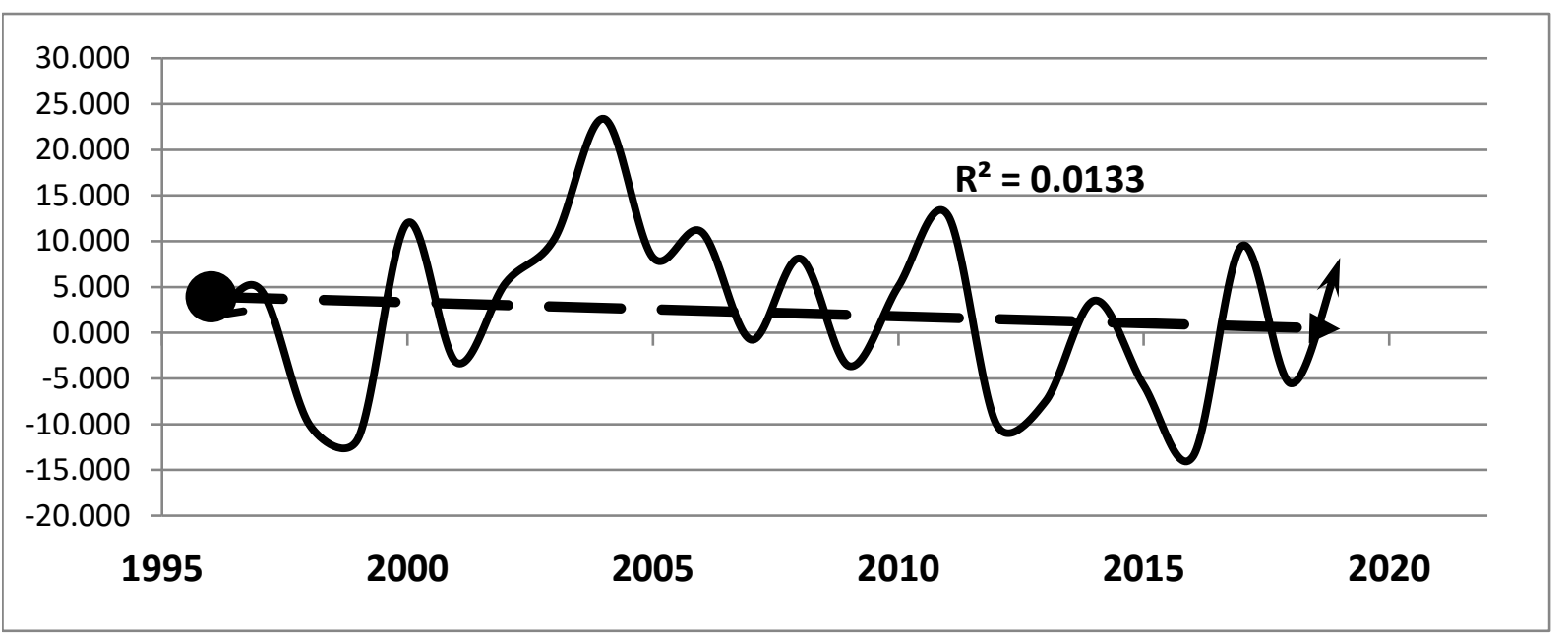

Source: Census and Economic Information Center (CEIC), 2020

a big extant. Among these the war on terror is one simple example. The war on terror damages tourism to a big extant (Raza \& Jawaid, 2013). Instead of various crises, tourism was proved to be a big source of income and employment. In 2013 contribution from tourism to the Gross Domestic Product (GDP) was $3.1 \%$ with $6.2 \%$ of the total employment (Abdur \& Muhammad, 2015). In 
2016 the income raised to US\$19.4 billion 6.9\% of the GDP (Pakistan Tourism Development Corporation, 2019).

Khyber Pakhtunkhwa is famous for tourism due to scenic views, archeological heritage and religious monuments and sources of tourist attractions. It is the smallest province of Pakistan decorated with unique climate diversity (Israr, et al., 2009). As mercury level is raised beyond 30 ${ }^{\circ} \mathrm{C}$, tourists around the world starts movement toward the mountainous regions of Khyber Pakhtunkhwa, such as Naran, Shougran, Natia Gali, Kohistan. Swat, Chitral and Kaghan valleys, famous for summer tourism. These mountainous regions are decorated with various scenic views include sky high mountains, glaciers, rivers, lakes, water falls, and forest (Sanaullah, et al., 2020). This tourism not only good for tourists and residence of the area, but also contribute toward national economy (Arshad, Iqbal, \& Shahbaz, 2018, and Arif, \& Shikirullah, 2019). Therefor it was aimed to estimate the expected losses for improvement and suitable repair during the ongoing pandemic

\section{Methods}

This manuscript is based on secondary data collected from the official web sites of Government of Pakistan and world famous data bases. The following links were the major sources of information.

1. COVID-19 related data was taken from official web site of Pakistan. http://covid.gov.pk/stats/pakistan

2. Data on tourism growth rate was collected form Official website of tourism department of Pakistan, http://www.tourism.gov.pk/index.html

3. Tourist Types were identified from a report published by USAID and ministry of tourism in 2011 (USAID, 2011), https://www.scribd.com/document/315165832/VisionDocuments-KPK

4. Data related to tourism revenues, GDP was collected from Census and Economic Information Center (CEIC) https://www.ceicdata.com/en/country/pakistan

5. Data related to foreign tourists were collected from three different sources

6. Information regarding various investments was collected from the various national newspapers as referred inside this paper.

7. Excel spread sheet was used for data compilation and analysis.

\section{Results and discussion}

\section{Domestic tourism}

The term "domestic tourism" is used for the tourist visiting different parts from inside the country. In this category tourist of one geographic location give visit to another location during their free time (Suhail, \& Khalid, 2011). These visits are for various purposes. In this regards it can be placed and discussed under seven sub categories (Fig. 2). The most common one is social call. Under this category, friends and family member of one place visit another. This type of tourism is very common and has two purposes.
Fig. 2: Types of domestic tourism in Pakistan

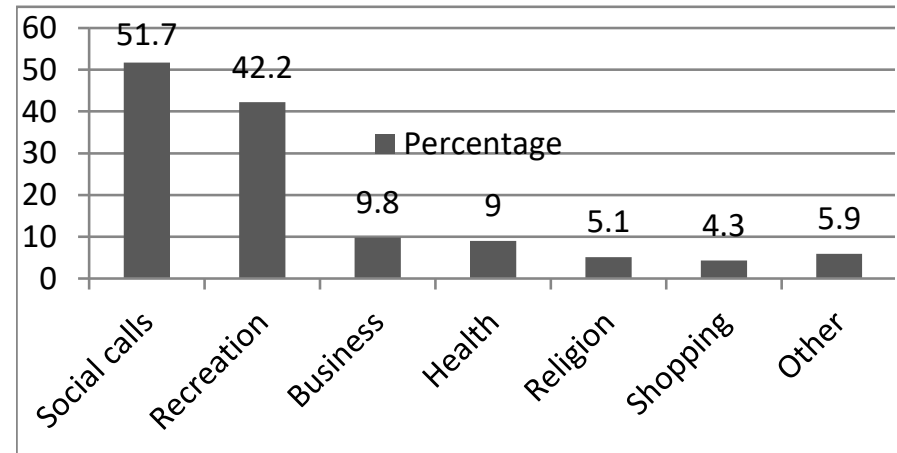

Source: United States Agency for International Development (USAID), 2011 
One is to meet near and dear after a long time. This type of tourism is always active throughout Pakistan. As most of the people are working outside their locality, therefore, when they have time, they prefer to see their friends and family members. In this regard the receiving family is also waiting for such occasion. Such tourism is active throughout the year. In winter season, people from the northern mountainous area are visiting southern plain areas of Pakistan. In summer season the temperature of the upper half of Khyber Pakhtunkhwa is pleasant and always enjoyable for the guest visitor from southern plain area. The stay period is usually ranged from one weak to two months (Sanaullah, et al., 2020).

The second category is recreation. Mostly, rich people visit different areas of Pakistan, especially the northern mountainous areas for recreation. These people have no residential arrangement and are always dependent on hotels and restaurants. The stay period is ranged from one weak to one month. This group is considered the soul of tourism in Khyber Pakhtunkhwa, because they purely needed the services of the local people on payment.

In Pakistan 46.7 million tourists were recorded in 2012. 19 percent of the total (8.8 million) visited Khyber Pakhtunkhwa. Due to various condition of the country, fluctuation is always there. When the situation is peaceful and favorable, there is increase, when there is some problem, there is decrease. The COVID-19 will badly effect social interaction and recreation activities. In this way $93.9 \%(51.7+42.2 \%)$ tourists may avoid to visit other areas. Decrease is also possible on the other types of tourism, i.e. business, religion and shopping (Fig. 2).

COVID-19 will badly affect labor market also. At present 1.17 million labors are attached with food and accommodation, 3.49 millions are attached with transport. In this way a total of 4.66 million labors will be hampered directly due to decrease in tourist activities (Iftikhar, 2020).

International/Foreign Tourists: Tourists coming from other countries are called international or foreign tourists. Foreign tourists can be divided into five categories (Fig. 3). Large numbers of tourist with $39.2 \%$ were interested to spend holidays in Pakistan followed by friends and families category with $27 \%$ (United Nation, 1994). This category is linked with India. As some of the families are spread over both the countries, India and Pakistan and are visiting each other on regular base. There is fluctuation in this category, mostly depended on the political situation between Pakistan and India and visa policy. These visits are irrespective of season. The COVID-19 may have no impact on this group. When political situations between India and Pakistan are favorable, they may visit Pakistan.

Fig 3: Major Categories of foreign tourist

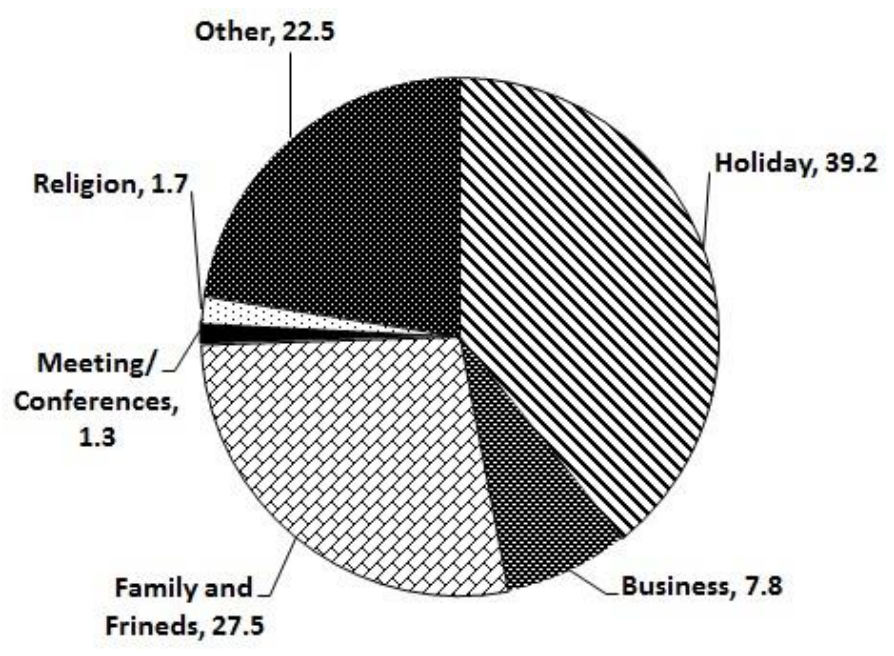

Source: United Nation 1994 These visitors usually come for family matters and visit to historic places or other areas are of secondary importance. In this manner, due to COVID-19, 66 percent $(39.2+27.5)$ visitors will be 
out of the circle. Another group visiting Pakistan on regular bases are for religious purpose but their percentage is very low $1.7 \%$. To facilitate Sikh plagiarisms, Pakistan make a lot of investment to facilities Sikh community. Due to the concept of social distance, they may also not visit Pakistan frequently and will be a big disappointment for Pakistan as well as for Sikh community. Official visitor (meeting and conferences) is the only category that may be active and officials from other countries may visit to Pakistan. Again, if the online facilities become functional, this category may also not visit Pakistan.

If we look into the historic trend, a regular decrease has been observed in international visitors during 1992-2003 (Fig. 4). Foreign tourism was slowly on the raise during 2004-11. Due to continuous terrorism for more than 20 years, foreign tourists dropped to the lowest level in 2013.

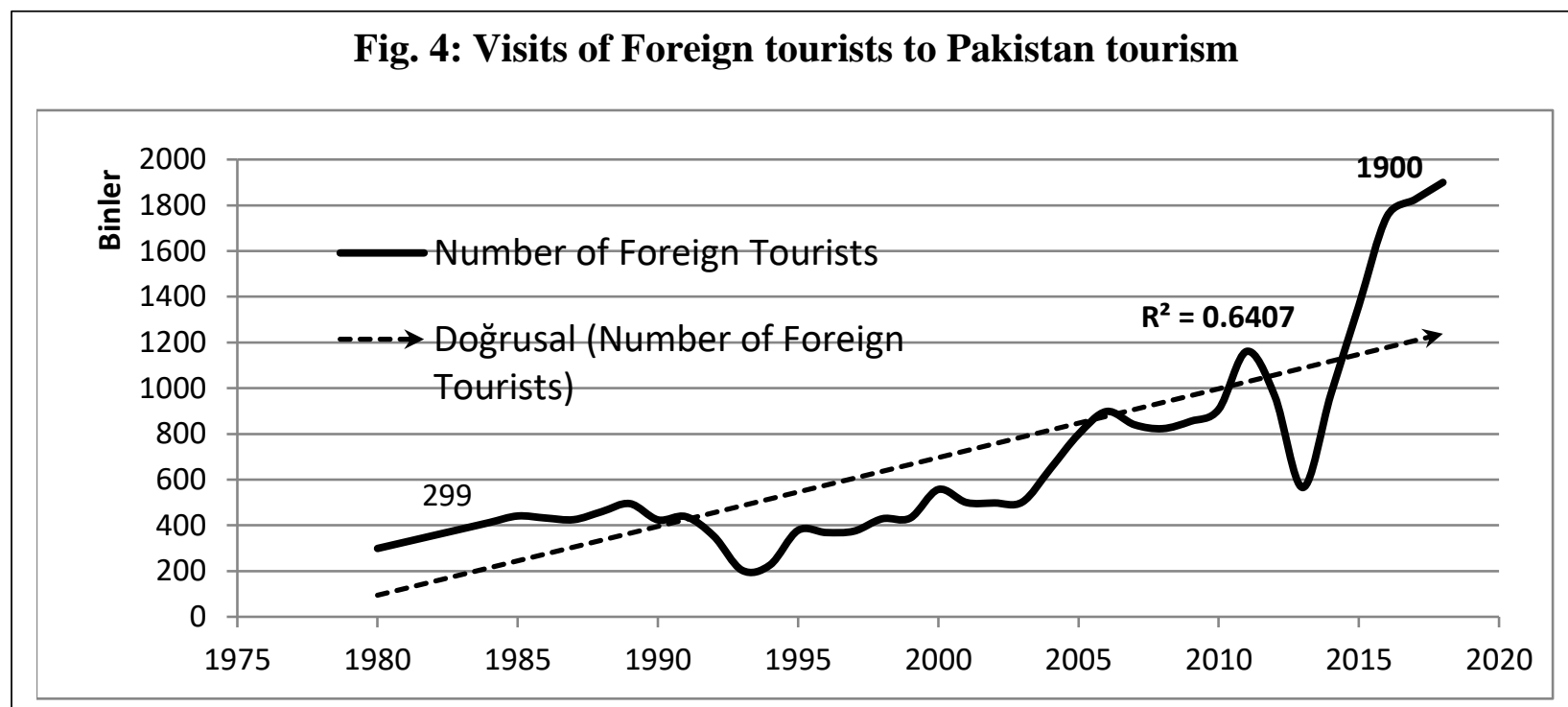

Source: Census and Economic Information Center (CEIC), 2020

After 2014 there was a regular increase. In 2019, the number of foreign visitors' to 1900 thousands, the highest figure in the history of Pakistan tourism (Fig. 4). During 2018-19 the numbers of national and international tourists were toward increase. In response, the government of Pakistan invested millions of rupees in developmental activities such as development of infrastructure and hotels. A new tourist policy was approved (Abid, 2019). The aim of this policy was to support and organize tourism and convert it into a full fledge economic activity.

\section{Investment and expected Income}

During 2013-19 Pakistan has launched various projects for bringing sustainability in tourism. The aim behind Swat motorway and Hazara Motorway was to encourage tourism. Total costs of Swat motorway and Hazara motorway were 40 billion and 35 billion respectively (Rana M., May 25, 2016). First phases of both the motorways have been completed and opened for public. The government of Pakistan has also planned $2^{\text {nd }}$ phases of Swat motorway by allocating Rs. 57.5 billion (Government of Khyber Pakhtunkhwa, 2019). Tourism department was expecting big increase in tourists' activities during summer of 2020. As per 2018 estimate by World Travel and Tourism Council, Pakistan's tourism related revenue was US\$20.18 billion with $7.1 \%$ contribution 
to the GDP (Fig. 5). It was expected that it will grow up 36 billion in the coming decade (Riaz, 2018).

Pakistan also invested 5 billion rupees in the last five years on development of new parks, cultural

Fig. 5. Percent contribution of Tourism to GDP

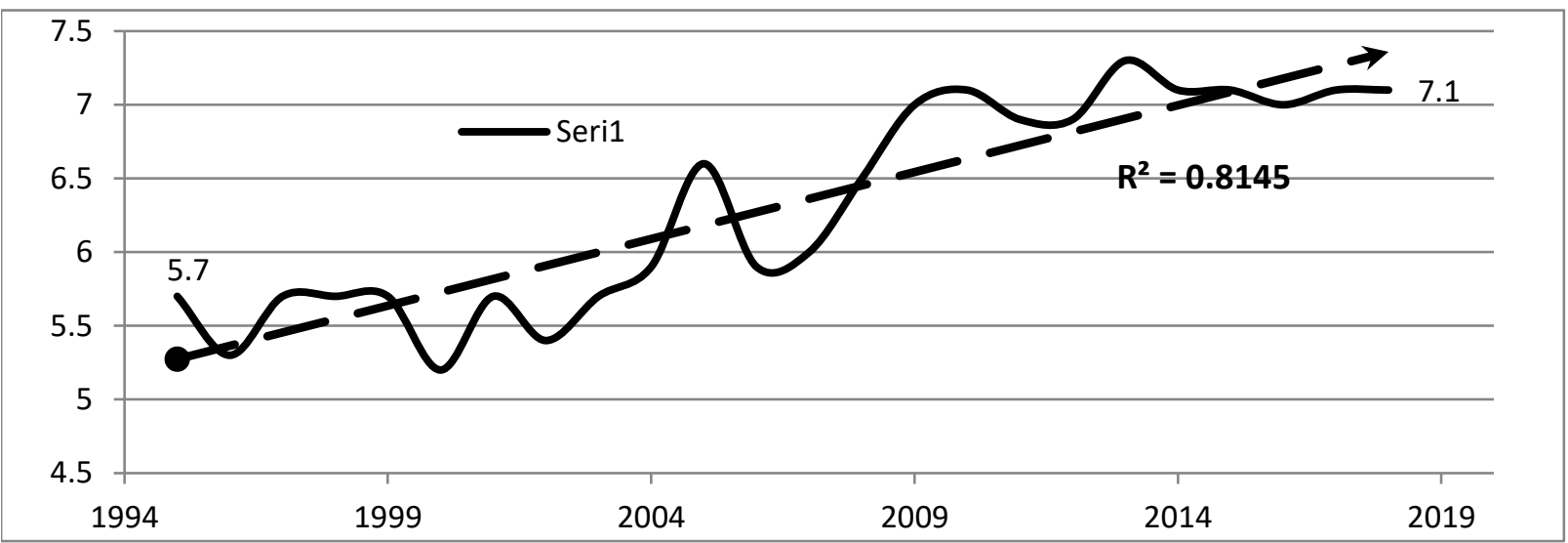

center, rest houses, along with trained tour operator jobs for the local. In few years' time 400 rest houses were constructed. Khyber Pakhtunkhwa alone invested 1.4 billion rupees (Government of Khyber Pakhtunkhwa, 2017). The government has planned to privatize and commercialized the government owned rest house and make it available for common person (Rolf and Sidra, 2018). Similarly nine projects were approved in annual development plan in 2017-18 for development of northern mountainous area with a focus on national parks for the purpose to attract more tourist as well protect bio-diversity conservation (Government of Khyber Pakhtunkhwa, 2019). Under $18^{\text {th }}$ constitutional amendment, title of the old act "The Pakistan Hotel and Restaurants Act 1976" was changed to "The Khyber Pakhtunkhwa Hotel Restaurants Amendment Act 2013" (The Khyber Pakhtunkhwa Hotel Restaurants Amendment Act 2013). These are the various developments toward sustainable tourism (Tourism Corporation Khyber Pakhtunkhwa, 2020). Under the new development it was planned to stream line all tourism related activities for the betterment of tourist. Government has also initiated online system for booking and registration.

As mentioned above after $18^{\text {th }}$ constitutional amendment, tourism is a provincial subject. Each province has got the right to plan tourism activities. In this regard the government of Khyber Pakhtunkhwa allocated Rs. 1.8 billion for construction of Kalam road, flooded away during 2010 flood. 6 rest houses were proposed for Mahu-dand Lake. Similarly Malam Jabba tourist spot was destroyed during terrorism, has been restored now. Six rest houses were planned between Naran and Batakundi tourist spots. It was also in planned to convert the inaccessible part in to tourist spot by making it accessible to a common person.

According to an estimate made during 2019, about 8.8 million tourists were recorded during the year 2019. This generated a handsome amount of Rs. 12.26 billion and was a big source of income for the government as well as the local residence. For the year 2020 a revenue target of Rs.36 to 50 billion was set (Rana, 2016). It was also planned to make the tourist activities safe and easy. For this purpose the government of Pakistan was in the process of institutionalization. As a result three time increase was recorded in foreign tourists during 2013-16. In 2020 more foreign tourist were 
expected to come (Fig. 5). As per estimate the long term target was 2.3 trillion for Pakistan in which the contribution from Khyber Pakhtunkhwa was 5.8 percent. Till 2027 the expected income was 204 billion from tourism in Khyber Pakhtunkhwa province.

Since 2014 Tourism department of tourism was with attempts to re-visit the various proposals. In 2020 it was planned that all roads leading toward tourist area will be completed. It was planned to make the visa process easy for tourist and attract foreigner for tourism. It was also planned to conserve the archeological sites. For this 500 million was approved for Swat areas only.

\section{Status of COVID-19 and it Impacts on Tourism in Pakistan}

Like other countries, Pakistan also observed lockdown, with the idea that the COVID-19 will come under control (Nafees \& Khan, 2020). This lock down can be divided into three phases. The first phase was strict and no one was allowed to move freely. All shops, hotels, restaurants, industry, schools \& colleges, except pharmacy and grocery shops were closed. In the second phase, the

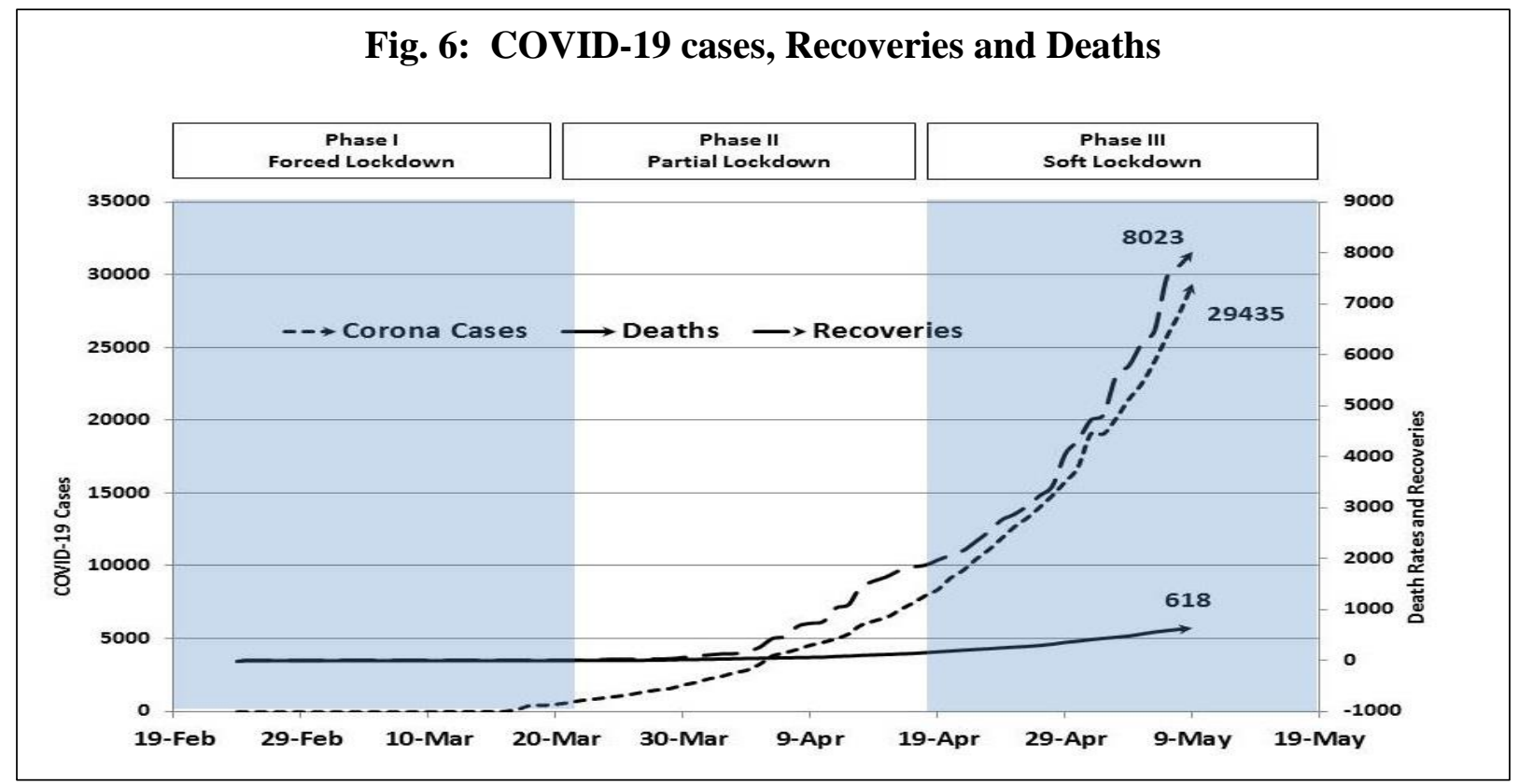

lockdown was relaxed a little by allowing some shops in construction activities were opened with the idea to help out the labor community. As clear from Fig. 6, there is a steady increase during $2^{\text {nd }}$ phase of lockdown. But being as a developing country, it was not possible to keep, even the partial lockdown continue. Therefore, the lockdown was relaxed and was termed as soft/smart lockdown. In the third phase major shops and businesses were opened with some restrictions. All the shopkeepers were given a set of standard operating procedures (SOPs) to be observed during business and keep the shops for eight hours only (Box. 1). The shops were allowed to keep open for 4 days a week for 8 hours only. 
By analyzing the graph (Fig. 6) a regular increase can be seen in COVID-19 cases along with increase in recoveries. Deaths were also there with a low ratio. Soft lockdown, the $3^{\text {rd }}$ phase is under strict observation with the idea to change it or keep it continuing. During this lockdown there is complete ban on public transport, parks, hotels and restaurants. In such situation tourism is simply next to zero. It is expected that some places may be opened for tourism in the near future. Again, international tourists are not expected to come for recreation or visit historical places.

To minimize the COVID-risk during soft lockdown, Pakistan prepared various SOPs guidelines for various places, such as mosques, shops, banks and airports (Box. 1). The lockdown was relaxed with the condition that public will strictly observed these SOPs. Hotels, restaurants and wedding hall owners are also demanding such SOPs with the demand to open their businesses. At this stage, one thing is clear that almost every country has observed lockdown in one form or another for more than two months with the idea that the world will get rid of coronavirus. Some decrease in COVID19 was recoded due to lockdown but couldn't be presented as a practical solution (Sardar, Nadim, \& Chattopadhyay, 2020 and Alvarez, Argente, \& Lippi, 2020). Now the soft lockdown along with SOPs is an alternate solution to overcome on COVID-19 associated hazards. If this experiment is successful, it will pave the way to prepare SOPs for hotels and restaurants also. In such situation, Pakistan, along with other country can re-initiated tourism activities.
BoX. 1: Standard Operating Procedures Guidelines for stores, Managers and general public regarding preventive measures to minimize the risk of COVID-19

- The staff should wash hands with soap and water frequently or use an alcohol-based (70\%) hand sanitizer

- Ensure the availability of alcohol based hand and sanitizer (at least $70 \%$ alcohol) at the store entrance for the customers.

- Make sure each customer sanitizes has hand before entering the store and while leaving

- Ensure the availability of thermal guns at entrance and allow customers only after checking temperature.

- Don not allow the customer with cough and flue to enter the store

- To ensure the space does not get crowded, allow people to enter the shop only in small groups.

- Customers and salesperson should maintain the safe distance of 6 feet (and preferably 2 meters) among each other.

- Disinfect the most frequently used surfaces by the customers such as shopping trollies, door, handles, cashier counter, product racks etc., with $0.5 \%$ diluted bleach lor $60-80 \%$ diluted alcohol solution/

- Disinfect the floor with bleach or alcohol-based surface cleaner regularly at equal intervals. (disinfectant formulations such as sodium hypochlorite with concentration of $5000-6150 \mathrm{ppm}$ to $500-615 \mathrm{ppm}$ free chlorine are used for environmental surface cleaning)

- The ATM machines should be cleaned with alcohol swab after every customer use and make available a hand sanitizer beside each machine. the credit/debit card machine available at cashier counter should also be disinfected frequently.

- Each salesperson and receptionist must ensure the use of gloves.

- The rest areas for staff should be disinfected regularly and should be used in compliance to the social distancing measure (i.e. 6 feet) among each other.

- The sick staff members should practice social distancing and must keep a track of their symptoms. Separate guidelines for management of cough, fever, flue during covid-19)

- Keep reminding the customer to buy as per their need to prevent hoarding of products.

- Ensure the public display of notices promoting and hygiene and social distancing inside the stores as well as outside the stores, buildings and plaza.

- Ensure queue control, maintaining the advised 6 feet distance, outside of shops and other essential premises that remain open.

- The store manager and staff must keep themselves updated with the updated instructions issued by the government and show strict compliance to them.

Source: Ministry of National Health Service, Government of Pakistan, 2020

\section{Conclusion}


Pakistan is basically a tourist's country and was famous for both foreign and domestic tourism. The tourism department started its efforts in 2011 and invested more than 90 billion on road network, hotels, parks and archeological sites. Domestic tourism was in placed to some extent. International tourism was just started. The COVID-19 brought both types of tourism to zero again. In this way all the investments during 2011-19 seems to be a total loss. The earning, as estimated was almost $7.1 \%$ of the GDP which is equivalent to US\$. 20.18 billion per year. How Pakistan well compensate this loss, is a question for the future leadership and planner. At this stage, everyone is looking toward vaccine for COVID-19. In the meantime we have to learn how to live with COVID19 in and safe manner and work on SOPs for different business and keep economic activities continue.

\section{References}

Abdur R. A. \& Muhammad A. Q. (2015). Tourism receipts and economic growth: Empirical evidence from Pakistan International Journal of Research. 2(2): 14011412:http://internationaljournalofresearch.org/.

Abid A., Dec 27, (2019). Pakistan announces its 10-year national tourism policy.

Alvarez, F. E., Argente, D., \& Lippi, F. (2020). A simple planning problem for covid-19 lockdown (No.w26981). National Bureau of Economic Research.DOI:10.3386/w26981.

Arif, A. M., \& Shikirullah, A. S. (2019). Tourism problems in Pakistan: An analysis of earlier investigations. WALIA journal 35(1): 122-126, 2019 Available online at www.Waliaj.comction, 2, 46-56.https://doi.org/10.1016/j.ijdrr.2012.08.001.

Arshad, M. I., Iqbal, M. A., \& Shahbaz, M. (2018). Pakistan tourism industry and challenges: a review. Asia Pacific Journal of Tourism Research, 23(2), 121-132.

Asgary, A., Anjum, M. I., \& Azimi, N. (2012). Disaster recovery and business continuity after the 2010 flood in Pakistan: Case of small businesses. International journal of disaster risk redu.

Bianchi, R. V. (2002). Towards a new political economy of global tourism. Tourism and development: Concepts and issues, 265-99.

Chen, C. D., Chen, C. C., Tang, W. W., \& Huang, B. Y. (2009). The positive and negative impacts of the SARS outbreak: A case of the Taiwan industries. The Journal of Developing Areas, 281-293. https://www.jstor.org/stable/40376284.

Cohen, E. (2012). Globalization, global crises and tourism. Tourism recreation research, 37(2), 103-111.

Dawn, 2018. 1.75m tourists visited Pakistan in 2017, says PTDC. DAWN Daily News paper April 25, 2018. https://www.dawn.com/news/1403800.

Directorate of tourist services, 2010. The Khyber Pakhtunkhwa Hotel Restaurants Amendment Act 2013. 
https://dts.gkp.pk/.

Delener, N. (2010). Current trends in the global tourism industry: evidence from the United States. Revista de Administração Pública, 44(5), 1125-1137.https://doi.org/10.1590/S003476122010000500006 .

https://dts.gkp.pk/.

Dwyer, L. (2005). 27 Trends underpinning global tourism in the coming decade. Digitally signed by TeAM YYePG DN: $c n=$ TeAM YYePG, c= US, o= TeAM YYePG, ou= TeAM YYePG, 529. Global tourism, third edition Editied by William F. Theobald, 2005.

Government of Khyber Pakhtunkhwa, (2017). Annual development program. Planning and Development Department, Govt. of Khyber Pakhtunkhwa, page 236.http://www. pndkp.gov.pk.

Government of Khyber Pakhtunkhwa, (2019). Khyber Pakhtunkhwa integrated tourism development project: environmental and social management framework. Department of Tourism, Khyber Pakhtunkhwa. Pakistan. http://documents.worldbank.org/curated/pt/654151551246028495/pdf/Environmentaland-Social-Management-Framework.pdf.

Haseeb, M., Xinhailu, A. B., Khan, J. Z., Ahmad, I., \& Malik, R. (2011). Construction of earthquake resistant buildings and infrastructure implementing seismic design and building code in northern Pakistan 2005 earthquake affected area. International Journal of Business and Social Science, 2(4):168-177.

http://library.fes.de/pdf-files/bueros/pakistan/14791.pdf

Iftikhar A., 2020. COVID-19 and labour market. Centre for Labour Research. URL: https://clr.org.pk/covid-19-labour-market/.

Israr, M., M. M. Shafi, N. Ahmad, N. Khan, S. Baig and Z.H. Khan. (2009). Eco tourism in Northern Pakistan and challenges perspective of stakeholders. Sarhad J. Agric. 25(1): 113120.

Muhammad I., Malik M. S., Naushad K., Nafees A., Sultan B. \& Zafar H. K., (2009). Eco tourism In Northern Pakistan and challenges perspective of stakeholders. Sarhad J. Agric. Vol.25, No.1, 2009.

Nafees M. \& Khan F. Pakistan's response to COVID-19 pandemic and efficacy of quarantine and partial lockdown: A Review. Electron J Gen Med. 2020;17(6):em240. https://doi.org/10.29333/ejgm/7951.

Officials say tourism will help create jobs for youth. SAMAA news network. https://www.samaa.tv/news/2019/12/pakistan-announces-its-10-year-national-tourismpolicy/.

Papatheodorou, A., Rosselló, J., \& Xiao, H. (2010). Global economic crisis and tourism: Consequences and perspectives. Journal of Travel Research, 49(1), 39-45.

"Position paper on devolution of tourism in Pakistan" Pakistan Institute for Parliamentary Services.

Rana M., May 25, (2016). Cost of Hazara motorway enhanced to Rs 35 billion. Daily time Islamabad. https://dailytimes.com.pk/80259/cost-of-hazara-motorway-enhanced-to-rs-35billion/.

Raza, S. A., \& Jawaid, S. T. (2013). Terrorism and tourism: A conjunction and ramification in Pakistan. Economic Modelling, 33, 65-70.https://doi.org/10.1016/j.econmod.2013.03.008 
Riahaq. H, Jan 19, (2018). Pakistan's $\$ 20$ billion tourism industry is Boomi. World Travel and Tourism Council. http://www.riazhaq.com/2018/01/pakistans-20-billion-tourismindustry.html

Rolf P. \& Sidra S. (2018). Implementation of the $18^{\text {th }}$ constitutional amendment.

Sanaullah, F., Rabbi, S. A., Khan, Z., \& Zamin, M. (2020). Visitors' willingness to pay for conservation of the biodiversity and tourism in Kalam valley of Khyber Pakhtunkhwa, Pakistan. Sarhad Journal of Agriculture, 36(1), 81-94.

Sanaullah, F. Rabbi, S. Ali, Z. Khan and M. Zamin. (2020). Visitors' willingness to pay for conservation of the biodiversity and tourism in Kalam valley of Khyber Pakhtunkhwa, Pakistan. Sarhad Journal of Agriculture, 36(1): 81-94. http://dx.doi.org/10.17582/journal.sja/2020/36.1.81.94.

Sardar, T., Nadim, S. S., \& Chattopadhyay, J. (2020). Assessment of 21 days lockdown effect in some states and overall India: a predictive mathematical study on COVID-19 outbreak. Xiv preprint arXiv:2004.03487.

Suhail, M \& Khalid, M. (2011). Vision document for tourism sector of Khyber Pakhtunkhwa, agricultural marketing legal framework. United States Agency for International Development. https://www.scribd.com/document/315165832/Vision-Documents-KPK.

The News, January 13, (2020). National tourism strategy for 2020 on the cards. The daily news, Issamabad, https://www.thenews.com.pk/print/597839-national-tourism-strategy-for2020-on-the-cards

The News, December (2019). Swat motorway phase-II: KP CM wants modalities for project worked out.

https://www.thenews.com.pk/print/578341-swat-motorway-phase-ii.

United Nation, (1994). The culture impact of international tourism in Pakistan. The United National, New York. 